\title{
Impact of climate change on weeds in agriculture: a review
}

\author{
Kristian Peters • Laura Breitsameter • Bärbel Gerowitt
}

Accepted: 22 July 2014 / Published online: 7 August 2014

(C) The Author(s) 2014. This article is published with open access at Springerlink.com

\begin{abstract}
Over the past decades, climate change has induced transformations in the weed flora of arable ecosystems in Europe. For instance, thermophile weeds, late-emerging weeds, and some opportunistic weeds have become more abundant in some cropping systems. The composition of arable weed species is indeed ruled by environmental conditions such as temperature and precipitation. Climate change also influences weeds indirectly by enforcing adaptations of agronomic practice. We therefore need more accurate estimations of the damage potential of arable weeds to develop effective weed control strategies while maintaining crop yield. Here we review the mechanisms of responses of arable weeds to the direct and indirect effects of climate change. Climate change effects are categorized into three distinct types of shifts occurring at different scales: (1) range shifts at the landscape scale, (2) niche shifts at the community scale, and (3) trait shifts of individual species at the population scale. Our main conclusions are changes in the species composition and new species introductions are favored, which facilitate major ecological and agronomical implications. Current research mainly considers processes at the landscape scale. Processes at the population and community scales have prevalent importance to devise sustainable management strategies. Trait-climate and niche-climate relationships warrant closer consideration when
\end{abstract}

\footnotetext{
K. Peters $(\triangle) \cdot B$. Gerowitt

Faculty of Agricultural and Environmental Sciences, Crop Health, University of Rostock, Satower Str. 48, 18051 Rostock, Germany

e-mail: kristian.peters@uni-rostock.de

L. Breitsameter

Centre of Biodiversity and Sustainable Land Use (CBL),

Section Agriculture and the Environment, University of Göttingen,

Grisebachstr. 6, 37077 Göttingen, Germany
}

modeling the possible future distribution and damage potential of weeds with climate change.

Keywords Agroecology · Arable biodiversity $\cdot$ Weed management - Weed control - Weed species composition . Functional trait $\cdot$ Ecological niche $\cdot$ Central Europe

\section{Contents}

1. Introduction $\ldots \ldots \ldots \ldots \ldots \ldots \ldots \ldots \ldots \ldots$

2. Direct effects of climate change on weeds ........ 2

3. Indirect effects of climate change on weeds via land use and management ...................... 3

4. General principles of the weeds' reactions . . . . . . . 3

5. Range shifts .................... 4

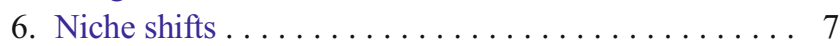

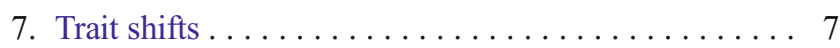

8. Discussion and implications for agronomy and research ......................... 8

9. Conclusions ............................ 10

Acknowledgments ......................... 10

References . . . . . . . . . . . . . . . . . . . . . . . . 11

\section{Introduction}

Over the past decades, some distinct transformations have been recorded in the weed flora of arable ecosystems in Europe (e.g., Schroeder et al. 1993; Sutcliffe and Kay 2000; Weber and Gut 2005; Fried et al. 2008; Novak et al. 2009; Potts et al. 2010; Andreasen and Streibig 2011; Kolarova et al. 2013; Salonen et al. 2013). For example, increasing numbers of thermophile weeds such as Amaranthus retroflexus (Fig. 1) and Abutilon theophrasti became established in more northern 


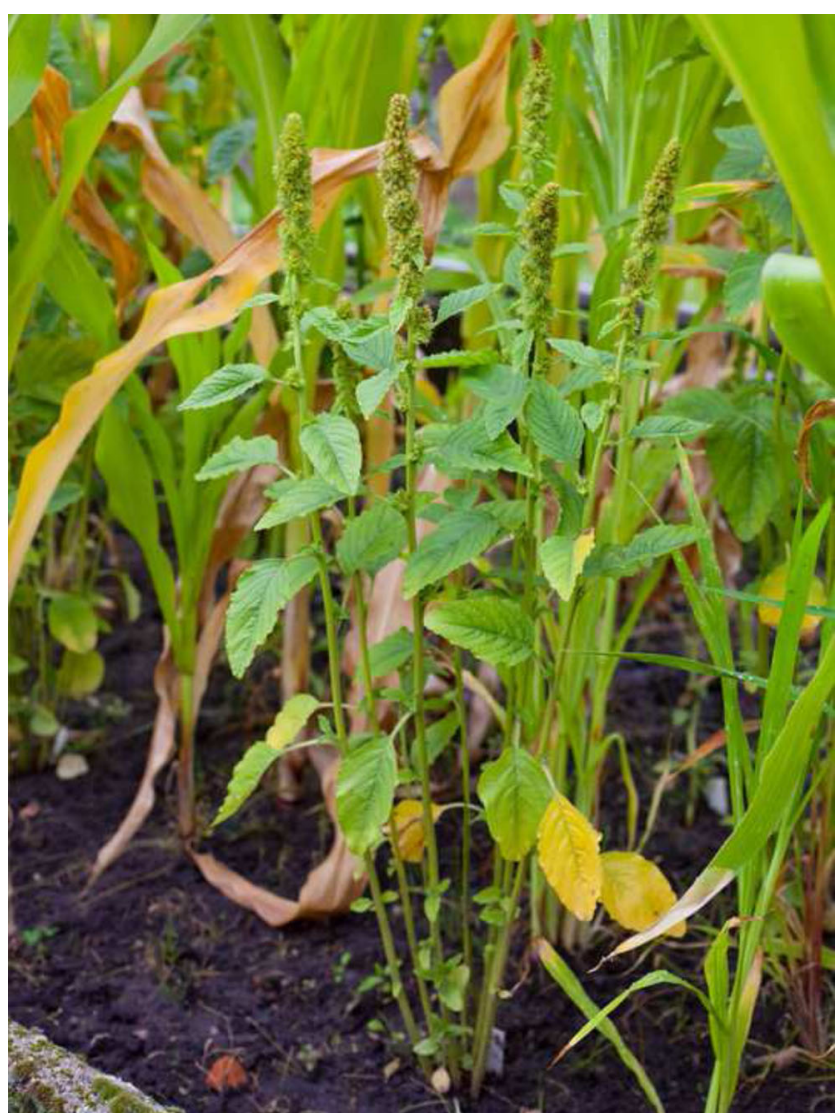

Fig. 1 Photo of Amaranthus retroflexus growing within maize

areas, including exotic and potentially invasive species such as Panicum dichotomiflorum and Datura stramonium (Guillerm et al. 1990; Breitsameter et al. 2014). Some late emergers such as Chenopodium spp. and millet weeds such as Echinochloa spp., Setaria spp., Digitaria spp., and Sorghum halepense (Fig. 2) have expanded their distribution range (Mehrtens et al. 2005; Otte et al. 2006). Weeds that have formerly been of minor importance have regionally become highly relevant species ("chance species," see Baessler and Klotz 2006). These "upstarters" include species such as Stellaria media, Geranium spp., several species of the subfamily Polygonoideae, and some crucifer (Brassicaceae) weeds (Peters et al. 2009; Meissle et al. 2010). As a result, arable ecosystems and agronomy are faced with the need to adapt weed control to these altered conditions.

Climate change will cause further alterations in the arable weed species composition. Predicted rates of climate change exceed any of the observed rates of change of the past 420,000 years (Petit et al. 1999; Loss et al. 2011). As a result, climate change may become one of the most important determinants for the distribution of arable weeds (Pautasso et al. 2010). Climate change leads to altered environmental conditions such as altered temperatures and precipitation that directly affect arable weeds. Climate change also influences weeds indirectly by enforcing adaptations of farming methods

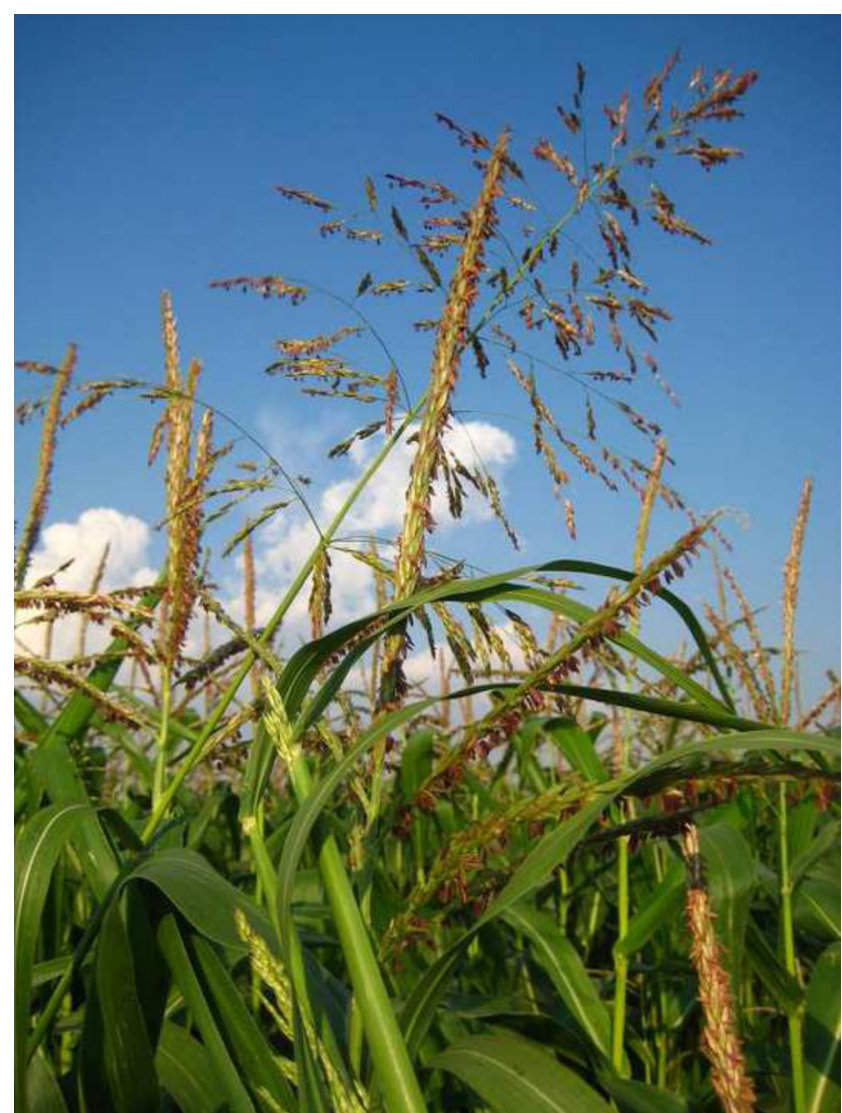

Fig. 2 Photo of wild Sorghum halepense as one profiting weed. Plants typically grow larger than maize plants

such as crop choice, sowing time, harvesting date, and other agronomical practices to these alterations (Fleming and Vanclay 2010).

In this review, we present three distinct kinds of shifts (range shift, niche shift, trait shift) acting at landscape, community, and population scales as the basic processes underlying current changes in the arable weed flora. We further highlight interrelations among these individual processes at different scales and apply existing ecological knowledge from natural and seminatural ecosystems to arable ecosystems. Yet, in contrast to the ecological concept of regime shifts, our concept of shifts represents small and gradual changes in the structure and function of the arable ecosystem (Scheffer et al. 2001; Brock et al. 2008; Samhouri et al. 2010). Finally, we point out areas for further research targeted at improving estimations of possible future effects of climate change on arable ecosystems that will help to devise management options to meet the challenges resulting from climate-mediated shifts.

\section{Direct effects of climate change on weeds}

Climate change involves rising temperatures (Tubiello et al. 2007; Gillett et al. 2011) and altered precipitation patterns, 
which also increase the probability for summer droughts in Europe (Bloomfield et al. 2006; Lobell and Burke 2008; Robinson and Gross 2010). Weeds are influenced by these altered abiotic conditions (Dukes et al. 2009; Singer et al. 2013). For example, wetter and milder winters are likely to increase the survival of some winter annual weeds, whereas warmer summers and longer growing seasons may permit thermophile summer annuals to grow in regions further north (Bloomfield et al. 2006; Walck et al. 2011; Hanzlik and Gerowitt 2012).

Furthermore, climate change is predicted to result in a higher frequency of extreme weather events such as heavy storms, summer droughts, and extreme cold spells (Diaz et al. 1999; Tubiello et al. 2007; Jentsch et al. 2009; Coumou and Rahmstorf 2012). As a result, seasonal fluctuations of the local climate are likely to occur more frequently and with larger amplitudes (Walther et al. 2002; Jentsch et al. 2009). Weeds with low phenotypic plasticity regarding these climatic changes are likely to decline. Both extreme weather events and rapid climatic changes disrupt the stability of arable ecosystems and increase the level of disturbance (Dukes and Mooney 1999).

Due to human actions, the concentration of atmospheric greenhouse gases such as methane $\left(\mathrm{CH}_{4}\right)$, nitric oxides, sulfur dioxide $\left(\mathrm{SO}_{2}\right)$, ozone $\left(\mathrm{O}_{3}\right)$, carbon dioxide $\left(\mathrm{CO}_{2}\right)$, and gaseous water $\left(\mathrm{H}_{2} \mathrm{O}\right)$ will rise in the future (Patterson 1995). The effect of increased levels of $\mathrm{CO}_{2}$ on plants has been intensively studied (e.g., Zangerl and Bazzaz 1984; Ziska 2003; Rogers et al. 2008). In brief, $\mathrm{C}_{3}$ plants benefit from rising $\mathrm{CO}_{2}$ levels physiologically. As several studies suggest, however, rising temperatures can override the stimulating effects of $\mathrm{CO}_{2}$ on photosynthesis (the Calvin cycle) of $\mathrm{C}_{3}$ plants (Batts et al. 1997; Morison and Lawlor 1999). The negative effect of higher temperatures on $\mathrm{C}_{3}$ plants depends on the norm of reaction of the plant species and the prevailing environmental conditions (Patterson 1995). By contrast, photosynthesis of $\mathrm{C}_{4}$ plants is more effective compared to that of $\mathrm{C}_{3}$ plants at higher temperatures, but $\mathrm{C}_{4}$ photosynthesis is usually not affected by atmospheric $\mathrm{CO}_{2}$ enhancement (Carter and Peterson 1983; Ziska 1997).

\section{Indirect effects of climate change on weeds via land use and management}

Arable ecosystems are defined and shaped by human interference, which differentiates them from any natural and seminatural ecosystem. Weeds in arable ecosystems are adapted to ecological idiosyncrasies resulting from the various farming practices (Grime 1977). Land use and management practices are influenced by climatic changes (Fleming and Vanclay 2010). As weeds are closely associated with the cropping system (Pysek et al. 2005; Andreasen and Skovgaard 2009;
Cimalova and Lososova 2009; Gunton et al. 2011), climate change has an indirect influence on the occurrence of weeds via crop management and land use.

The effects of climate change on arable ecosystems are widely discussed in literature (e.g., Sala et al. 2000; Fuhrer 2003; Pautasso et al. 2010). Yet, just a few papers cover the effects of climate change on weeds in relation to specific crops (Patterson et al. 1984; Alberto et al. 1996; Tungate et al. 2007). To assure harvest in the face of climate change, farmers adapt cropping systems and management measures, for instance, by implementing different crop rotations, crop sowing dates, irrigation, and tillage methods (Kaukoranta and Hakala 2008; Fleming and Vanclay 2010; Daccache et al. 2012). Farmers are also likely to choose new, climatically suited crops or cultivars that are better adapted to warm and dry conditions (Bloomfield et al. 2006; Tokatlidis 2013). Extreme weather events in the future will probably set yield at higher risks, which may lead to an increase in pesticide usage and fertilizer input (Baessler and Klotz 2006; Lososova et al. 2006). Arable land use is also projected to be expanded to cover less fertile soils while becoming more uniform across the landscape (Olesen and Bindi 2002). Ultimately, politics (e.g., decisions, legislative framework, public money) and market economics (e.g., demand for commodities, private and corporate investment) additionally influence agronomic practices (Olesen and Bindi 2002).

Rising atmospheric $\mathrm{CO}_{2}$ is likely to alter the competition between weeds and crops; yet, the outcome depends on the individual set of conditions. On one hand, some weeds may be able to evolve successful attributes more rapidly than crops due to their high genetic variation and plasticity (Baker 1965). On the other hand, breeding of $\mathrm{CO}_{2}$-efficient crops such as wheat, maize, or soybean is likely to advance in the future (Ziska et al. 2005; Tokatlidis 2013). Elevated $\mathrm{CO}_{2}$ levels and warmer and wetter conditions can also alter the efficiency of certain herbicides by influencing the physiology of plants (Poorter and Navas 2003; Dukes et al. 2009).

\section{General principles of the weeds' reactions}

The effects of changing climatic conditions impact arable weeds in various ways. In order to persist in a local habitat, species have to respond to the changes of the environment (Woodward and Cramer 1996). These responses lead to shifts, which act at distinctive scales (see below). Generally, plant species have three options to avoid extinction (Lavorel and Garnier 2002; Pautasso et al. 2010):

1. Migration with a favorable climate, which leads to alterations of the distribution of weeds - a process called range shift. For migration, weeds need to possess appropriate propagule dispersion mechanisms. In arable 
ecosystems, this is often also provided by human actions (Kubisch et al. 2013). Range shifts act at the landscape scale (Jump and Peñuelas 2005).

2. Acclimation to changes in climate conditions basically refers to the response of species within their phenotypic plasticity without evolutionary adjustments (Pearman et al. 2008). These responses can be divided into tolerance and avoidance of climatic changes that lead to performance beyond the species' ecological optimum (Grime and Hodgson 1987; Lavorel and Garnier 2002). As a consequence, the fitness and the competitive ability of the weeds are either reduced or enlarged (Barrett 2000). Consequently, the realized niche is being altered, which leads to niche shifts. They act at the community scale and can be determined visually as composition shifts.

3. Adaptation to changes in climate conditions, which is often associated with the evolution of new properties or with the optimization of existing ones (Harlan and de Wet 1965; Carroll et al. 2007; Tungate et al. 2007). These individual biological adaptations of weeds, which are driven by natural selection, result in trait shifts. They become apparent at the population scale, but are brought about by morphological, physiological, and genetic processes at the individual plant scale.

Our literature search for this review revealed that agricultural research with regard to climate change has mainly considered processes at the landscape scale (Table 1). However, in most cases, range shifts are accompanied by processes at the community and population scales (Hulme and Barrett 2013; Ebeling et al. 2008). Especially trait shifts have infrequently been linked to climate change so far (Table 1). Moreover, most existing studies rely on literature or on meta-analysis of data (Table 1).

In order to understand the processes underlying the current transformations of the arable ecosystems, a more comprehensive knowledge of shifts at all scales is needed. In the following, we explain the ecological basis of these individual types of shifts. By highlighting some examples from current research, we relate them to the context of the responses of arable weeds to climate change. For reasons of an initial categorization, we present the different types of shifts as separate processes. However, it needs to be kept in mind that several shifts can be intermingled across the distinct scales they are acting at.

\section{Range shifts}

Range shifts represent the transformation of the distribution area of species and occur at the landscape scale, i.e., at a geographical area extending from several arable fields up to few hundred kilometers (Pearson and Dawson 2003; Petit et al. 2011). With recent climate change, plant species are expected to track the climate favorable to their growth (Jump and Peñuelas 2005). This is well investigated and documented for Europe (Cimalova and Lososova 2009; Silc et al. 2009; Walck et al. 2011; Hanzlik and Gerowitt 2012). Rising temperatures can cause species range boundaries to be moved further toward the poles (Walther et al. 2002). As a result, many $\mathrm{C}_{4}$ weeds such as $A$. retroflexus, Setaria spp., Digitaria spp., P. dichotomiflorum, and S. halepense are expected to extend their distribution range to locations further north (Fausey and Renner 1997; Weber and Gut 2005; Clements and Ditommaso 2011) (Figs. 1 and 2). Presumably, increased levels of precipitation during winter will additionally shift the range of many weed species moderately eastward in Europe (Skov and Svenning 2004; Bergmann et al. 2010). The effect of climate change on the number of weed species is likely to be more pronounced in northern regions of Europe, as the number of weeds is lower there than in southern regions (Holzner and Immonen 1982; Fried et al. 2008).

Opportunistic weed species possess the ability to track climate change by means of sophisticated dispersal and superior adaptation capabilities (Chapin et al. 1996; Bergmann et al. 2010; Pautasso et al. 2010). Human-promoted propagule dispersion via transport routes and trade can act as a trigger with certain species such as Ambrosia artemisiifolia (von der Lippe et al. 2013; Milakovic et al. 2014), which is not always clearly distinguishable from climate-related mechanisms. Possibly due to an interaction of human actions and climatic changes, the maize weeds of the genus Setaria (Douglas et al. 1985; Wang and Dekker 1995) and A. theophrasti (Andersen et al. 1985; Warwick and Black 1986) have extended their range to Northern America.

If climate change occurs too rapidly, some species may be unable to track the climate to which they have adapted over time (Jump and Peñuelas 2005; Broennimann et al. 2006). In addition, species whose propagule transport mainly relies on biological dispersal mechanisms, habitat fragmentation, and dispersal barriers like mountains may also prevent range shifts (Bazzaz 1996; Grime 1997). This mainly appears to be the case for locally rare species such as Scandix pecten-veneris and Silene noctiflora (Lososova et al. 2006; Hyvönen et al. 2012).

In order to sustain a population in a novel habitat, weeds must persist after they have become established (Weiher et al. 1999; Smith et al. 2011). As a consequence, range shifts are often accompanied by natural selection leading to genetic and evolutionary adjustments to the novel environments (Levin 2009; Lavergne et al. 2010; Richardson et al. 2013). These evolutionary processes result in trait shifts (see Section 7). The level of evolutionary adaptations is highest at the expanding front (the colonizing edge) and at the boundary of the range (Angert et al. 2011; Doxford and Freckleton 2012). 


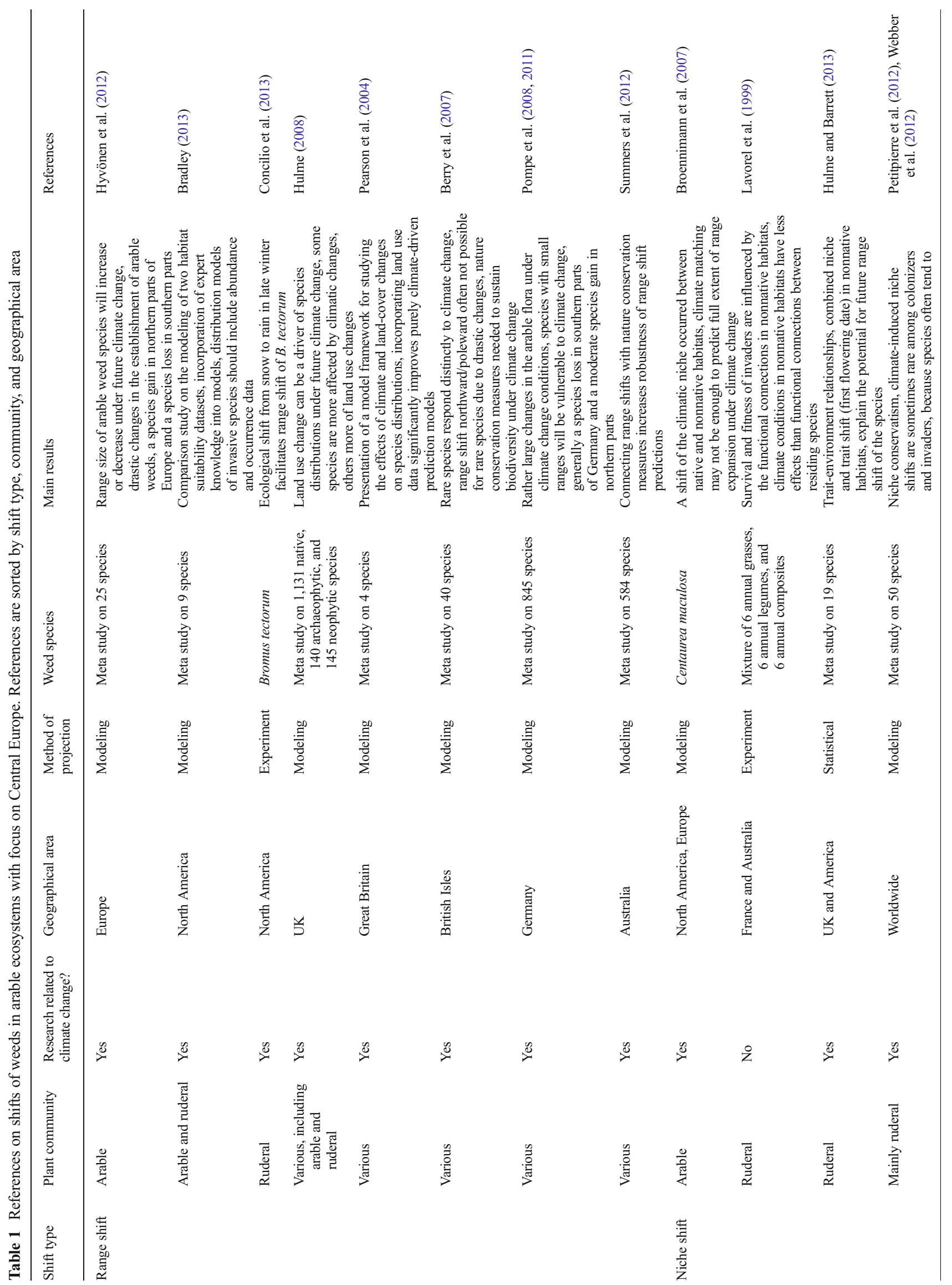




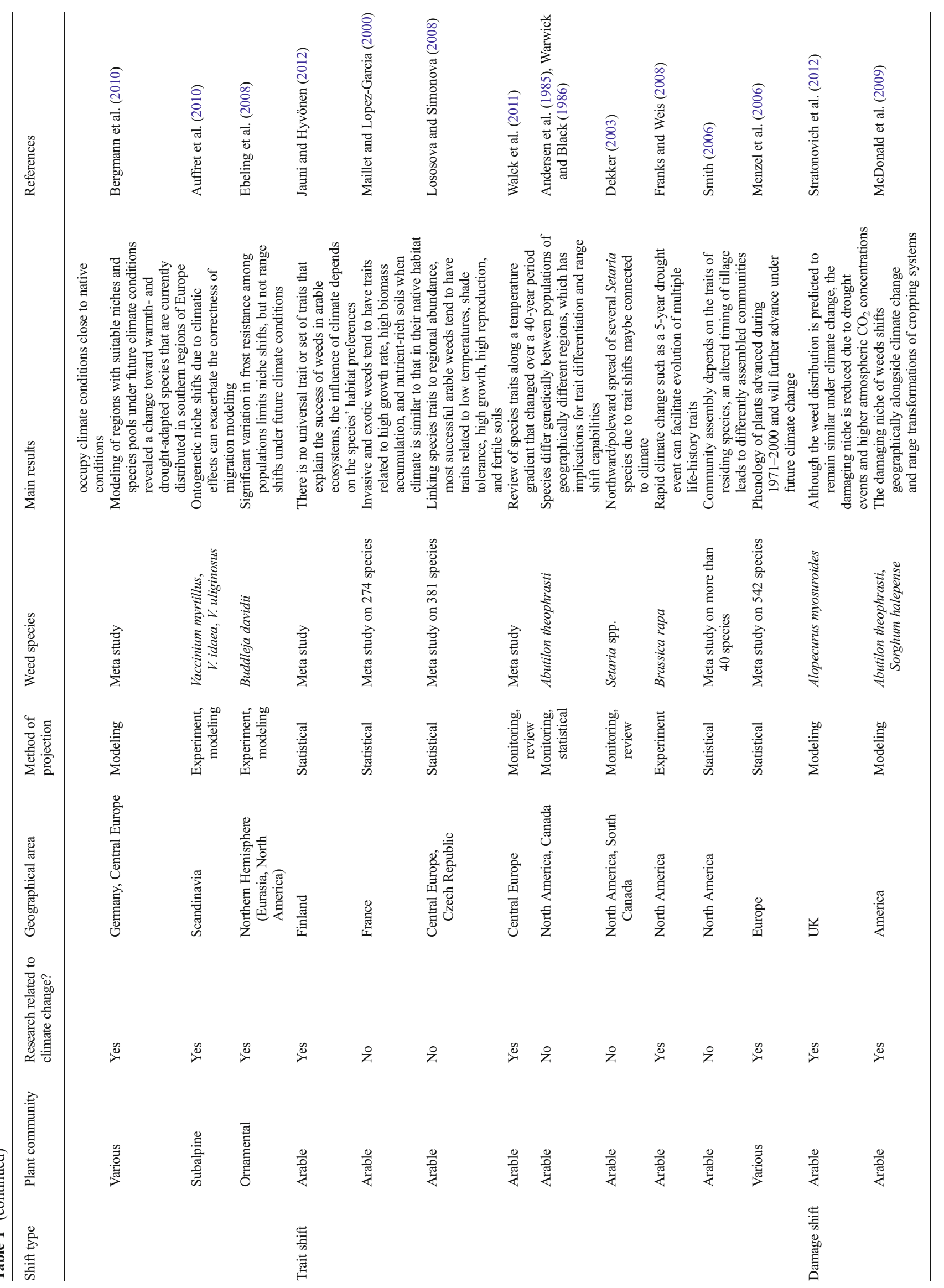




\section{Niche shifts}

In ecosystems, every species occupies an ecological niche. In this review, we follow the niche concept of Hutchinson (1957). Herein, the fundamental niche is defined as an $n$ dimensional hypervolume, with each dimension representing the environmental resources required by species for survival (Colwell and Rangel 2009). Limited environmental resources and interspecific competition by other organisms reduce the size of the fundamental niche of a species to the realized niche. Along with the niches of other species, all realized niches are arranged in the niche pool in a particular habitat (Silvertown 2004; Fried et al. 2010). The size of the niche pool defines the maximum space available to be occupied by niches.

Changing climatic conditions lead to a transformation of the size and the shape of the niche pool, which affects the species niches inside the pool and, consequently, causes alterations in the community (Chapin et al. 1996). There are very few examples of climate-mediated niche shifts in arable ecosystems. Broennimann et al. (2007) demonstrated that Centaurea maculosa actively realized a niche shift. This species was introduced from Europe to Northern America and extended its niche by adapting certain traits. Like in this example, niche shifts are often accompanied by other shifts.

Most agronomic actions are designed to remove weeds from the local species pool (Holzner and Immonen 1982). As a result, farming practices - which vary depending on climate - cause disturbance to the system and influence the construction of niches by creating niche gaps (Clements et al. 1994; Eriksson 2013). Niche gaps also result from disturbance as caused by extreme climate events such as extreme wind, frost, rain, and other mechanical disruptions. Niche gaps directly affect the abundance and cover of weeds due to the removal of plants caused by disturbance (Booth and Swanton 2002; Nogues-Bravo 2009). This process is often followed by a temporary increase in the availability of nutrients and a reduction in competition (Stohlgren et al. 1999). Ecologically, niche gaps represent empty space in the niche pool. Dekker (2003) describes niche gaps as "opportunity space" for exotics and invaders. Yet, niche gaps as caused by extreme weather events can also be an additional opportunity for weeds to emerge (Hobbs and Huenneke 1992). Thus, niche gaps most often become apparent by relatively high fluctuations between species or high introduction rates of species (MacArthur 1955).

Yet, most disturbances disrupt the structure of the ecosystem inconspicuously by disorganizing or removing ecological linkages between species (MacArthur 1970; Clements et al. 1994). Weed species are intermingled with each other within the local community to a varying degree. As a result, they react on the community level rather than as single entities (Weiher et al. 1999). Still, the processes linking the responses of weed communities to plasticity, competition, and disturbance are not well understood so far (Post et al. 2001; Nogues-Bravo 2009; Estrella et al. 2009).

It has been argued that each kind of disturbance has stronger effects in less diverse ecosystems and that these ecosystems can be more prone to the introduction of arable newcomers (Drake 1990; Walther et al. 2002). In arable ecosystems with diverse weed communities, more weed species are present that can fill niche gaps and prevent the establishment of new species (Booth and Swanton 2002). In less diverse arable communities, the fewer resident species occupy empty niche space more slowly and less efficiently after disturbance (Rejmanek 1989). Due to their large niche size and few, but very stable linkages, "keystone species" exert a large effect on the community. If a keystone species is removed, community function will be changed drastically (Booth and Swanton 2002). Weed communities with a history of frequent herbicide treatments often lack keystone species, which lead to less stable arable communities that are often prone to the establishment of arable newcomers and invasive species (Fox and Fox 1986). Invaders often exert symptoms of becoming new keystone species themselves (Guillerm et al. 1990; Clements and Ditommaso 2011).

The underlying processes of niche shifts of arable weeds are most often invisible and difficult to quantify. However, as niche shifts usually lead to an altered dominance of species in the community, they often become apparent as changes in the composition of arable weed species (Chapin et al. 2000; Booth and Swanton 2002). Composition shifts can be determined as they result from changes in the abundance and the population structure of weed species (MacArthur 1955; Elton 1958; Harlan and de Wet 1965; Singer et al. 2013). For example, the current species pool in Germany (Pompe et al. 2008; Bergmann et al. 2010) and other European countries (Ihse 1995; Menzel et al. 2006; Hyvönen 2011; Potts et al. 2010) already indicates a change toward weeds that are adapted to warm and dry summer conditions.

\section{Trait shifts}

Traditionally, a plant trait represents a measurable attribute of a species (Raunkiaer 1934; Weiher et al. 1999). In recent decades, efforts have been made to devise functional groups of attributes with relation to ecological factors or resources (Grime 1977; Craine et al. 2001; Lavorel and Garnier 2002; Gunton et al. 2011). The ecosystem supplies the plant with nutrients, energy, atmospheric gases, and water. Only those species prevail that possess the appropriate sets of (functional) traits suited for making use of the resources given in a certain area (McIntyre et al. 1999). The trait set of a species is the basis of its functional relationship to the environmental resources and to other species within the ecosystem. Recently, multivariate analyses help in determining these functional 
connections (Lososova et al. 2006; McGill et al. 2006; Fried et al. 2008; Jauni and Hyvönen 2012). A changing climate influences the supply of resources, and as a consequence, it alters the functional connections of traits (Diaz et al. 1998; Jauni and Hyvönen 2012). Climate change hence selects those species featuring the appropriate set of traits (Keddy 1992; Grime 1997) and leads to shifts in the traits of plant populations (Carroll et al. 2007; Tungate et al. 2007). Changing environmental conditions may favor traits of dominant (e.g., invasive) species, which are able to significantly alter ecosystem function (Wilson and Agnew 1992; Schulze and Mooney 1994).

Here, by the term "trait shift" we refer to visible and measurable alterations of morphological or physiological attributes of individual plant species caused by changes in climatic conditions. Trait shifts mainly become apparent at the population scale and result from natural selection of individuals that perform differently under altered environmental conditions. They are usually caused by changes in the genotype and, hence, represent evolutionary adjustments to the altered environmental conditions (Levin 2009; Lavergne et al. 2010; Richardson et al. 2013). In fragmented populations, climate-mediated trait shifts may result in the formation of climatic ecotypes that fit the local conditions. Trait shifts are a prerequisite to niche shifts and can cause range shifts, if they enable a species to proliferate in areas with different environmental conditions.

As described, trait shifts are often related to phenology, morphology, physiology, and reproduction. In arable land use systems, they do not only occur as a consequence of climatic changes, but also as a result of altered agronomical practice. The adjustment of sowing dates to changing spring and autumn temperature conditions that farmers used to practice in the past decades is relevant in this context (Otte et al. 2006; Chmielewski et al. 2004). For example. the germination temperature range of Chenopodium ficifolium as measured in the 1950s was between 30 and $40^{\circ} \mathrm{C}$ (Lauer 1953), whereas in the late $1980 \mathrm{~s}$, it was between 0 and $30^{\circ} \mathrm{C}$. According to Otte (1991), this trait shift mainly occurred as an adaptation to earlier spring crop sowing dates, which were adopted by farmers during that period of time in Germany. Similar findings were reported for Chenopodium album that flowered earlier in northern regions of the UK (Froud-Williams 1996).

S. media, a plant endemic to Central Europe, had originally been restricted to damp, nutrient-rich places around riverbanks (Lohmeyer 1954). The species has adapted some biological traits such as flowering time and germination characteristics to contemporary farming practices (Lososova and Simonova 2008). Evolutionary adjustments such as polyploidy may have occurred in parallel (Rauber 1977). In arable ecosystems, the species now features a larger plasticity regarding both warmer winter conditions and farming practices such as high fertilization. The weed is now able to germinate and flower during the whole year within a larger temperature range (Baessler and Klotz 2006; Fried et al. 2010).

Weeds with a low plasticity regarding emergence temperatures and time of emergence may be exposed to disadvantages with climate change, as future conditions drive the emergence timeframe beyond the optimum considered for the species (Nogues-Bravo 2009; Walck et al. 2011). The inability to shift certain traits is often connected to niche conservatism, which is shown by many specialist and rare species (Wiens and Graham 2005; Lososova et al. 2006; Pearman et al. 2008).

\section{Discussion and implications for agronomy and research}

Land use, agricultural practice, and abiotic environmental conditions including climate select for certain weed species based on the suitability of their ecophysiological profiles. As a result, they act as filters, which determine the species composition of the arable weed community in a particular site (Pearson and Dawson 2003; Cimalova and Lososova 2009; Navas 2012; Stratonovich et al. 2012). The various filters act at different scales (Fig. 3). Whereas climate and land use mainly act at the landscape scale, agricultural management practices prevalently determine the weed composition at the community scale. Changing climatic conditions influence the properties of the individual filters, for example by altering the availability of resources (e.g., precipitation) or by causing the farmers to implement altered farming practices and to eventually cultivate crops with different attributes (Tanaka and Koike 2011) (Fig. 3). As a consequence, species are eliminated from the community, if their traits are not congruent with the new conditions (Keddy 1992; Diaz et al. 1998; Lavorel and Garnier 2002). Climate change further alters biotic interactions, which influence the realized niches of the species (May and MacArthur 1972; Keddy 1992; Blumenthal and Hufbauer 2007). This leads to (functional) trait shifts, which, in turn, influence the composition of the weed community (Navas 2012). A changing climate can eliminate (e.g., local extinction) or add (e.g., colonization, invasion) species to the local species pool and transform the community composition (Drake 1990; Booth and Swanton 2002). Hence, in the future, agronomy will have to consider the interference of new opportunistic weeds that may replace weed species that were formerly of importance.

For example, in recent years, weeds have increased that show traits related to long-growing seasons (Otte et al. 2006). In former times, the sum of growing degree days was too low to allow seeds of $A$. theophrasti to fully ripen during the growing season in Central Europe (Westerman et al. 2012); longer growing seasons during the past 50 years (Menzel et al. 2006) allowed the species to successfully produce ripe seeds. Climate change involving warmer temperatures will thus 


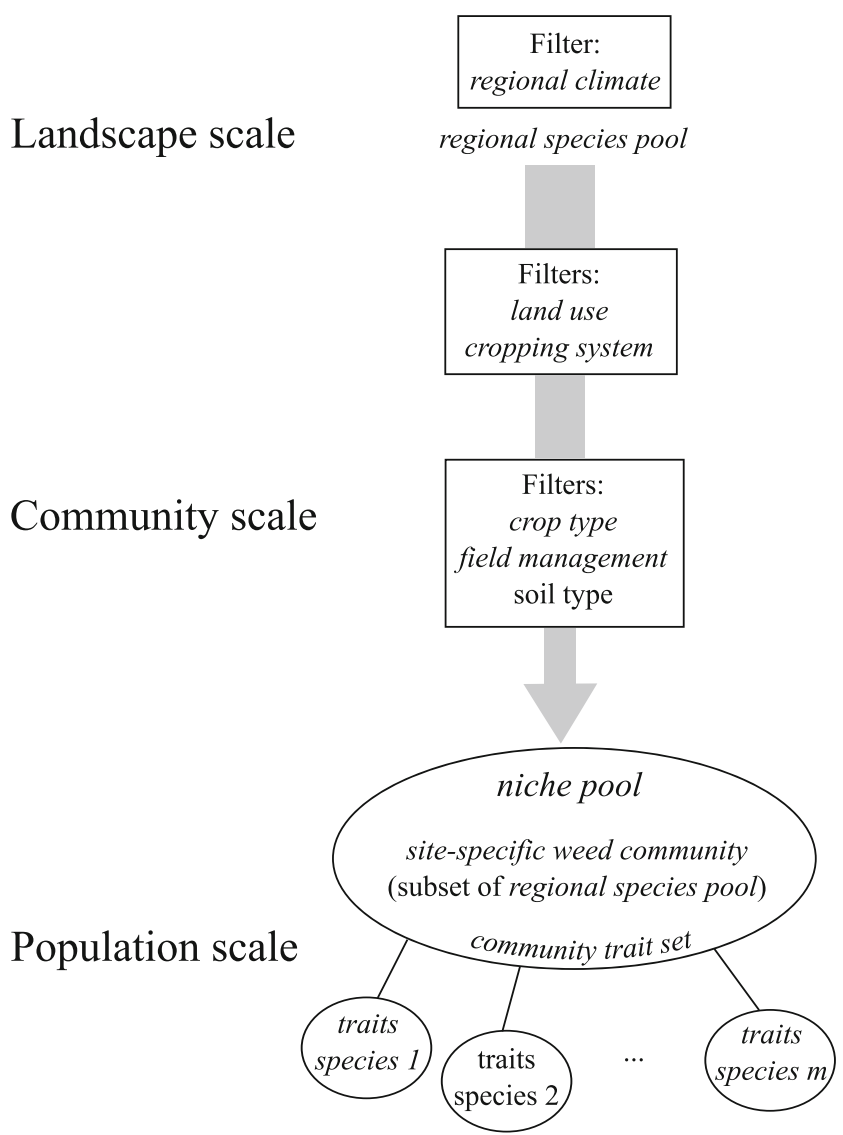

Fig. 3 Filters that determine the arable species composition acting at three distinct scales. Factors as influenced by climate change are shown in italic font. Due to climate change, the regional species pool is altered and species are possibly removed and/or added. As a result, the local niche pool will contain a different number of species occupying different niches. Species may have a different trait disposition with climate change. The weed community is site-specific and is also influenced by the sets of traits of the species

allow the species to successfully reproduce and to get established further north in Central Europe.

Among the species that benefit from climate change, there are certainly those that already possess or will develop opportunistic attributes related to climate change. Attributes such as drought and heat tolerance, the $\mathrm{C}_{4}$ photosynthesis type, the date of first flowering, high seed production, small and light seeds, great dispersal capability, a fast life cycle, and regeneration after disturbance have been identified to be particularly relevant with regard to the predicted future changes. Most of these traits are also beneficial for weeds under intensive and uniform cultivation practices (Hulme 2008). Weeds that benefit from current environmental change often have high phenotypic plasticity with regard to climate. This suggests that a single set of traits that explain the success of certain weed species is unlikely to be found (Richardson and Pysek 2006). With regard to traits related to the exploitation and use of water, climate change will favor weeds that are equipped with the $\mathrm{C}_{4}$ carbon fixation pathway such as $A$. retroflexus (Lloret et al. 2005; Walther et al. 2009; Gassó et al. 2009) (Fig. 1) and Echinochloa crus-galli (Barrett and Wilson 1981; Otte et al. 2006). Wetter and milder winters will increase the survival of some winter annuals such as S. media and Sisymbrium species that already possess strong traits related to these climate conditions (Walck et al. 2011; Hanzlik and Gerowitt 2012).

Crop management often selects for weeds whose attributes are similar to those of the crop and weeds that are adapted to frequent disturbance typically for intensive practices (Essl et al. 2011). For example, due to the limited specificity of herbicides (Clements et al. 1994; Ziska et al. 1999), crucifer (Brassicaceae) weeds that are closely related to oilseed rape, such as Sisymbrium species, Descurainia sophia, and Capsella bursa-pastoris are nowadays common in fields in Germany (Hanzlik and Gerowitt 2012). In maize cropping, typical weeds appear to be genetically related millets such as E. crus-galli, Setaria spp., and Digitaria spp. (Mehrtens et al. 2005). They seem to be the outcome of short-term selection processes and their presence is mainly caused by modern management practices.

The introduction of arable newcomers as a result of climate-induced range shifts is often facilitated by farming practices and niche gaps (Maillet and Lopez-Garcia 2000), but also depends on the attributes of the resident and invading species (Lavorel et al. 1999; Chapin et al. 2000). Exotics and invaders are range-expanding plants that are at the boundaries of their distribution. These species often show increased adaptive evolutionary responses that enable them to cope with fluctuations better than the resident species (Linhart and Grant 1996; Barrett 2000). Increased disturbance as a result of extreme weather events can additionally act as a driver of trait differentiation in plant communities (Grime 2006; Jauni and Hyvönen 2012) and may already have benefited some alien species such as Centaurea solstitialis and Hypericum maculatum (Maron et al. 2007; Hierro et al. 2013). Agronomical practice should, therefore, aim at mitigating niche gaps by cultural methods (e.g., crop rotation, sowing time, tillage). Integrated weed management (IWM) combines cultural methods with occasional herbicide use (Anderson 2007). Hence, herbicide use in the IWM concept helps to improve and steer the outcome of cultural control. By contrast, repeated herbicide treatments cause additional and new niche gaps.

As each weed population has its individual set of functional traits, within the community, these traits of several species add up to a "community trait set." By altering the weed species composition, a changing climate thus also alters the disposition and number of trait sets within the community. These processes will influence species niches, as well as agronomy and weed control. When accounting for the impact of climatemediated shifts on weeds and weed communities, in agronomy, a valuation is performed with regard to the potential damage or yield losses caused by weeds in crops. The term 
"damage niche" was shaped to account for the agronomic damage potential of weeds. Accordingly, the term "damage shift" addresses alterations of the damage potential of weeds in particular areas of their distribution against the backdrop of changing environmental conditions (McDonald et al. 2009; Stratonovich et al. 2012) (Table 1). For example, McDonald et al. (2009) modeled the geographical range of the damage niche for the two weed species $A$. theophrasti and $S$. halepense in the USA. With climate change, both species are projected to extend their damage niche further north. The two species are also important maize weeds in Europe (Salonen et al. 2001; Hyvönen 2011). For the UK, yield losses caused by Alopecurus myosuroides may be reduced because of climate change (Stratonovich et al. 2012). A more sophisticated understanding of climate-mediated trait shifts and connected niche shifts by measuring attributes of weeds and weed-crop interactions will help to anticipate the possible future damage niches of weeds and to devise management options (Howden et al. 2007; Neve et al. 2009; Gunton et al. 2011; Petit et al. 2011).

Prediction of the future damage niches of weeds is of prevalent importance for a sustainable weed management. In order to assure yields in the face of predicted future conditions and possible extreme weather events, famers may adopt more intensive crop protection practices in the future (Essl et al. 2011). Certain intensive management practices such as the inappropriate use of herbicides at frequent intervals, however, can facilitate the evolution of herbicide resistance in weed populations (Mortensen et al. 2000; Neve et al. 2009). Introgression of genes could be an important component of damage shifts as well, although it has not been intensively studied so far (Sakai et al. 2001; Jump et al. 2008). Regionally explicit predictions of the damage potential caused by weeds in the future may help to devise alternative and additional management options to herbicide treatment. Broader crop rotations for example may help to reduce the pressure from certain weeds.

In order to predict future changes, it is necessary to determine the functional connections between present environmental conditions and species attributes in order to estimate the future relevance of weeds. Besides selected species traits, the weed species composition is an indicator of the occurrence of underlying shifts. Impacts of climate change on arable ecosystems can thus be detected by a continuous monitoring of the weed species composition accompanied by an analysis of further recent transformations. Changes in weed composition result from the combined effects of range transformations, changes in the arrangement and size of niches, and the disposition of functional traits. Therefore, a stronger consideration of trait shifts is needed. The screening of population traits across the distribution range of weeds may support this aim (Petit et al. 2011).

The ability to predict the future damage potential of weeds is strongly related to modeling. With regard to climate change, bioclimatic envelope models (habitat suitability models) are currently widely used to predict the species' response to the altered environmental conditions (Pearson and Dawson 2003; Heikkinen et al. 2006; Fordham et al. 2013). Yet, most current modeling approaches have a limited accuracy as they mainly integrate processes at the landscape scale (Fordham et al. 2013). Most bioclimatic models only consider the fundamental niche of a species rather than the realized niche, which is explained by additional factors at community and population scales (Austin and Van Niel 2011). As a result, there may be a discrepancy between the observed results of experiments and the modeled distribution (Peters and Gerowitt 2014). Especially with rare species and invaders, additional data are needed to accurately estimate the potential for future shifts (Morin and Thuiller 2009; Hulme and Barrett 2013).

\section{Conclusions}

Shifts are the most important outcome of climate change in arable ecosystems. In agronomy and weed research, processes induced by climate change have, so far, received most interest in comprehensive studies at the landscape scale. We have revealed the influence of processes at other scales, namely niche and trait shifts. Range shifts are investigated with bioclimatic distribution models. As described above, deficiencies at the other scales can be expected to cause inconsistencies between observations and predictions of these models. Thus, knowledge of the underlying processes that lead to trait and niche shifts will probably enhance the prediction accuracy of bioclimatic distribution models when added to those that rely on range shifts. Hence, trait-climate relationships and species interactions warrant closer consideration when modeling the possible future distribution of species (Box 1996; Fordham et al. 2013; Hulme and Barrett 2013).

Currently, little original research is available on niche and trait shifts of arable weeds with regard to climate change. Research approaches on the impacts of climate change on weeds in arable ecosystems need to reflect the functional interrelations and have to take stronger focus on systemic approaches combining process-oriented with spatially explicit investigation. The sole consideration of the individual types of shifts is most unlikely to be sufficient to depict the effects of climate change. A promising option in this respect is to combine species distribution modeling with the monitoring of alterations in the weed species composition and with empirical experiments on weeds under altered conditions (Breitsameter et al. 2014).

Acknowledgments This study was supported by the Ministry for Science and Culture of Lower Saxony within the network KLIFF-climate impact and adaptation research in Lower Saxony. We thank Peter Juroszek and Jana Bürger for giving useful advice and for supplying literature. We also thank Christiane Wunderow for editing this manuscript. 


\section{References}

Alberto AMP, Ziska LH, Cervancia CR, Manalo PA (1996) The influence of increasing carbon dioxide and temperature on competitive interactions between a C3 crop, rice (Oryza sativa) and a C4 weed (Echinochloa glabrescens). Aust J Physiol 23:795-802

Andersen RN, Menges RM, Conn JS (1985) Variability in velvetleaf (Abutilon theophrasti) and reproduction beyond its current range in North America. Weed Sci 33:507-512

Anderson RL (2007) Managing weeds with a dualistic approach of prevention and control. A review. Agron Sustain Dev 27:13-18. doi:10.1051/agro:2006027

Andreasen C, Skovgaard IM (2009) Crop and soil factors of importance for the distribution of plant species on arable fields in Denmark. Agric Ecosyst Environ 133:61-67. doi:10.1016/j.agee.2009.05.003

Andreasen C, Streibig JC (2011) Evaluation of changes in weed flora in arable fields of Nordic countries - based on Danish long-term surveys. Weed Res 51:214-226. doi:10.1111/j.1365-3180.2010.00836.x

Angert AL, Crozier LG, Rissler LJ et al (2011) Do species' traits predict recent shifts at expanding range edges? Ecol Lett 14:677-689. doi: 10.1111/j.1461-0248.2011.01620.x

Auffret AG, Meineri E, Brunn HH et al (2010) Ontogenetic niche shifts in three Vaccinium species on a sub-alpine mountain side. Plant Ecol Divers 3:131-139. doi:10.1080/17550874.2010.498063

Austin MP, Van Niel KP (2011) Improving species distribution models for climate change studies: variable selection and scale. J Biogeogr 38:1-8. doi:10.1111/j.1365-2699.2010.02416.x

Baessler C, Klotz S (2006) Effects of changes in agricultural land-use on landscape structure and arable weed vegetation over the last 50 years. Agric Ecosyst Environ 115:43-50. doi:10.1016/j.agee. 2005.12.007

Baker HG (1965) Characteristics and modes of origin of weeds. In: Baker HG, Stebbins GL (eds) The genetics of colonizing species. Academic Press, New York, pp 147-168

Barrett SCH (2000) Microevolutionary influences of global changes on plant invasions. In: Mooney HA, Hobbs RJ (eds) Invasive species in a changing world. Island Press, Washington D. C., pp 115-139

Barrett SCH, Wilson BF (1981) Colonizing ability in the Echinochloa crus-galli complex (barnyard grass). I. Variation in life-history. Can J Bot 59:1844-1860. doi:10.1139/b81-245

Batts GR, Morison JIL, Ellis RH et al (1997) Effects of CO2 and temperature on growth and yield of crops of winter wheat over four seasons. Eur J Agron 7:43-52. doi:10.1016/S0378-519X(97)80009-8

Bazzaz FA (1996) Plants in changing environments. Cambridge Univ Press. $332 \mathrm{pp}$

Bergmann J, Pompe S, Ohlemüller R et al (2010) The Iberian Peninsula as a potential source for the plant species pool in Germany under projected climate change. Plant Ecol 207:191-201. doi:10.1007/ s11258-009-9664-6

Berry PM, O'Hanley JR, Thomson CL et al (2007) MONARCH 3 (modelling natural resource responses to climate change)-technical report. UKCIP Univ, Oxford

Bloomfield JP, Williams RJ, Gooddy DC et al (2006) Impacts of climate change on the fate and behaviour of pesticides in surface and groundwater - a UK perspective. Sci Total Environ 369:163-177. doi:10.1016/j.scitotenv.2006.05.019

Blumenthal DM, Hufbauer RA (2007) Increased plant size in exotic populations: a common-garden test with 14 invasive species. Ecology 88:2758-2765

Booth BD, Swanton CJ (2002) Assembly theory applied to weed communities. Weed Sci 50:2-13. doi:10.1614/0043-1745(2002) 050[0002:AIATAT]2.0.CO;2

Box EO (1996) Plant functional types and climate at the global scale. J Veg Sci 7(3):309-320. doi:10.2307/3236274
Bradley BA (2013) Distribution models of invasive plants over-estimate potential impact. Biol Invasions 15:1417-1429. doi:10.1007/ s10530-012-0380-0

Breitsameter L, Bürger J, Peters K et al (2014) Klimafolgenforschung zu Ackerunkräutern - Daten, Methoden und Anwendungen auf verschiedenen Skalen. Julius-Kühn-Archiv 443:123-132. doi:10. 5073/jka.2014.443.014

Brock WA, Carpenter SR, Scheffer M (2008) Regime shifts, environmental signals, uncertainty, and policy choice. In: Norberg J, Cumming GS (eds) Complexity theory for a sustainable future. Columbia University Press, New York, pp 180-206

Broennimann O, Thuiller W, Hughes G et al (2006) Do geographic distribution, niche property and life form explain plants' vulnerability to global change? Glob Chang Biol 12:1079-1093. doi:10.1111/ j.1365-2486.2006.01157.x

Broennimann O, Treier UA, Müller-Schärer H et al (2007) Evidence of climatic niche shift during biological invasion. Ecol Lett 10:701709. doi:10.1111/j.1461-0248.2007.01060.x

Carroll SP, Hendry AP, Reznick DN, Fox CW (2007) Evolution on ecological time-scales. Funct Ecol 21:387-393. doi:10.1111/j. 1365-2435.2007.01289.x

Carter DR, Peterson KM (1983) Effects of a CO2-enriched atmosphere on the growth and competitive interaction of a $\mathrm{C} 3$ and a $\mathrm{C} 4$ grass. Oecologia 58:188-193

Chapin FSIII, Bret-Harte MS, Hobbie SE, Zhong H (1996) Plant functional types as predictors of transient responses of arctic vegetation to global change. J Veg Sci 7:347-358. doi:10.2307/3236278

Chapin FSIII, Zavaleta ES, Eviner VT et al (2000) Consequences of changing biodiversity. Nature 405:234-242. doi:10.1038/35012241

Chmielewski FM, Müller A, Buns E (2004) Climate changes and trends in phenology of fruit trees and field crops in Germany, 1961-2000. Agric For Meteorol 121:69-78. doi:10.1016/S0168-1923(03)00161-8

Cimalova S, Lososova Z (2009) Arable weed vegetation of the northeastern part of the Czech Republic: effects of environmental factors on species composition. Plant Ecol 203:45-57. doi:10.1007/s11258-008-9503-1

Clements DR, Ditommaso A (2011) Climate change and weed adaptation: can evolution of invasive plants lead to greater range expansion than forecasted? Weed Res 51:227-240. doi:10.1111/j.1365-3180. 2011.00850.x

Clements DR, Weise SF, Swanton CJ (1994) Integrated weed management and weed species diversity. Phytoprotection 75:1-18. doi:10. 7202/706048ar

Colwell RK, Rangel TF (2009) Hutchinson's duality: the once and future niche. PNAS 106:19651-19658. doi:10.1073/pnas.0901650106

Concilio AL, Loik ME, Belnap J (2013) Global change effects on Bromus tectorum L. (Poaceae) at its high-elevation range margin. Glob Chang Biol 19:161-172. doi:10.1111/gcb.12032

Coumou D, Rahmstorf S (2012) A decade of weather extremes. Nat Clim Chang 2:491-496. doi:10.1038/NCLIMATE1452

Craine JM, Froehle J, Tilman DG et al (2001) The relationships among root and leaf traits of 76 grassland species and relative abundance along fertility and disturbance gradients. Oikos 93:274-285. doi:10. 1034/j.1600-0706.2001.930210.x

Daccache A, Keay C, Jones RJA et al (2012) Climate change and land suitability for potato production in England and Wales: impacts and adaptation. J Agric Sci 150:161-177. doi:10.1017/ S0021859611000839

Dekker J (2003) Evolutionary biology of the foxtail (Setaria) speciesgroup. In: Inderjit (ed) Weed biology and management. Kluwer Academic Publishers, The Netherlands, pp 65-114

Diaz S, Cabido M, Casanoves F (1998) Plant functional traits and environmental filters at a regional scale. J Veg Sci 9:113-122. doi: $10.2307 / 3237229$

Diaz S, Cabido M, Zak M et al (1999) Plant functional traits, ecosystem structure and land-use history along a climatic gradient in centralwestern Argentina. J Veg Sci 10:651-660. doi:10.2307/3237080 
Douglas BJ, Thomas AG, Morrison IN, Maw MG (1985) The biology of Canadian weeds. 70. Setaria viridis (L.) Beauv. Can J Plant Sci 65: 669-690. doi:10.4141/cjps85-089

Doxford SW, Freckleton RP (2012) Changes in the large-scale distribution of plants: extinction, colonisation and the effects of climate. $\mathrm{J}$ Ecol 100:519-529. doi:10.1111/j.1365-2745.2011.01902.x

Drake JA (1990) The mechanics of community assembly and succession. J Theor Biol 147:213-233. doi:10.1016/S0022-5193(05)80053-0

Dukes JS, Mooney HA (1999) Does global change increase the success of biological invaders? Trends Ecol Evol 14:135-139. doi:10.1016/ S0169-5347(98)01554-7

Dukes JS, Pontius J, Orwig D et al (2009) Responses of insect pests, pathogens, and invasive plant species to climate change in the forests of northeastern North America: what can we predict? Can J For Res 39:231-248. doi:10.1139/X08-171

Ebeling SK, Welk E, Auge H, Bruelheide H (2008) Predicting the spread of an invasive plant: combining experiments and ecological niche model. Ecography (Cop) 31:709-719. doi:10.1111/j.1600-0587.2008.05470.x

Elton CS (1958) The ecology of invasions by animals and plants. Methuen, London

Eriksson O (2013) Species pools in cultural landscapes - niche construction, ecological opportunity and niche shifts. Ecography (Cop) 36: 403-413. doi:10.1111/j.1600-0587.2012.07913.x

Essl F, Dullinger S, Rabitsch W et al (2011) Socioeconomic legacy yields an invasion debt. Proc Natl Acad Sci U S A 108:203-207. doi:10. 1073/pnas. 1011728108

Estrella N, Sparks TH, Menzel A (2009) Effects of temperature, phase type and timing, location, and human density on plant phenological responses in Europe. Clim Res 39:235-248. doi:10.3354/cr00818

Fausey JC, Renner KA (1997) Germination, emergence, and growth of giant foxtail (Setaria faberi) and fall panicum (Panicum dichotomiflorum). Weed Sci 45:423-425

Fleming A, Vanclay F (2010) Farmer responses to climate change and sustainable agriculture. A review. Agron Sustain Dev 30:11-19. doi: 10.1051/agro/2009028

Fordham DA, Mellin C, Russell BD et al (2013) Population dynamics can be more important than physiological limits for determining range shifts under climate change. Glob Chang Biol 19:3224-3237. doi: $10.1111 /$ gcb. 12289

Fox MD, Fox BJ (1986) The susceptibility of natural communities to invasion. In: Groves RH, Burdon JJ (eds) Ecology of biological invasions: an Australian perspective. Australian Academy of Science, Canberra, pp 57-66

Franks SJ, Weis AE (2008) A change in climate causes rapid evolution of multiple life-history traits and their interactions in an annual plant. J Evol Biol 21:1321-1334. doi:10.1111/j.1420-9101.2008.01566.x

Fried G, Norton LR, Reboud X (2008) Environmental and management factors determining weed species composition and diversity in France. Agric Ecosyst Environ 128:68-76. doi:10.1016/j.agee.2008.05.003

Fried G, Petit S, Reboud X (2010) A specialist-generalist classification of the arable flora and its response to changes in agricultural practices. Bio Med Central Ecol 10:1-11. doi:10.1186/1472-6785-10-20

Froud-Williams RJ (1996) Weeds and climate change: implications for their ecology and control. Asp Appl Biol 45:187-196

Fuhrer J (2003) Agroecosystem responses to combinations of elevated $\mathrm{CO} 2$, ozone, and global climate change. Agric Ecosyst Environ 97: 1-20. doi:10.1016/S0167-8809(03)00125-7

Gassó N, Sol D, Pino J et al (2009) Exploring species attributes and site characteristics to assess plant invasions in Spain. Divers Distrib 15: 50-58. doi:10.1111/j.1472-4642.2008.00501.x

Gillett NP, Arora VK, Zickfeld K et al (2011) Ongoing climate change following a complete cessation of carbon dioxide emissions. Nat Geosci 4:83-87. doi:10.1038/ngeo1047

Grime JP (1977) Evidence for the existence of three primary strategies in plants and its relevance to ecological and evolutionary theory. Am Nat 111:1169-1194. doi:10.1086/283244
Grime JP (1997) Climate change and vegetation. In: Crawley M (ed) Blackwell Science, Oxford, p Plant ecology

Grime JP (2006) Trait convergence and trait divergence in herbaceous plant communities: mechanisms and consequences. J Veg Sci 17: 255-260. doi:10.1111/j.1654-1103.2006.tb02444.x

Grime JP, Hodgson JG (1987) Botanical contributions to contemporary ecological theory. New Phytol 106:283-295. doi:10.1111/j.14698137.1987.tb04695.x

Guillerm JL, Floch E Le, Maillet J, Boulet C (1990) The invading weeds within the Western Mediterranean Basin. In: di Castri F, Hansen AJ, Debussche M (eds) Monogr Biol 65. Springer, pp 61-84. doi: 10. 1007/978-94-009-1876-4 5

Gunton RM, Petit S, Gaba S (2011) Functional traits relating arable weed communities to crop characteristics. J Veg Sci 22:541-550. doi:10. $1111 / j .1654-1103.2011 .01273 . x$

Hanzlik K, Gerowitt B (2012) Occurrence and distribution of important weed species in German winter oilseed rape fields. J Plant Dis Prot 119:107-120

Harlan JR, de Wet JMJ (1965) Some thoughts about weeds. Econ Bot 19: 16-24. doi:10.1007/BF02971181

Heikkinen RK, Luoto M, Araujo MB et al (2006) Methods and uncertainties in bioclimatic envelope modelling under climate change. Prog Phys Geogr 30:751-777

Hierro JL, Eren Ö, Villarreal D, ss MC (2013) Non-native conditions favor non-native populations of invasive plant: demographic consequences of seed size variation? Oikos 112:583-590. doi:10.1111/j. 1600-0706.2012.00022.x

Hobbs RJ, Huenneke LF (1992) Disturbance, diversity, and invasion: implications for conservation. Conserv Biol 6:324-337. doi:10. 1046/j.1523-1739.1992.06030324.x

Holzner W, Immonen R (1982) The agrestal weed flora and vegetation of the world. In: Holzner W, Numata M (eds) Biology and ecology of weeds. Dr. W. Junk, The Hague, pp 203-226

Howden SM, Soussana J-F, Tubiello FN et al (2007) Adapting agriculture to climate change. Proc Natl Acad Sci U S A 104:19691-19696. doi: 10.1073/pnas.0701890104

Hulme PE (2008) Relative roles of life-form, land use and climate in the recent dynamics of alien plant distributions in the British Isles. Weed Res 49:19-28. doi:10.1111/j.1365-3180.2008.00658.x

Hulme PE, Barrett SCH (2013) Integrating trait- and niche-based approaches to assess contemporary evolution in alien plant species. J Ecol 101:68-77. doi:10.1111/1365-2745.12009

Hutchinson GE (1957) Concluding remarks. Cold Spring Harb Symp Quant Biol 22:415-427. doi:10.1101/SQB.1957.022.01.039

Hyvönen T (2011) Impact of temperature and germination time on the success of a $\mathrm{C} 4$ weed in a $\mathrm{C} 3$ crop: Amaranthus retroflexus and spring barley. Agric Food Sci 20:183-190

Hyvönen T, Luoto M, Uotila P (2012) Assessment of weed establishment risk in a changing European climate. Agric Food Sci 21:348-360

Ihse M (1995) Swedish agricultural landscapes-patterns and changes during the last 50 years, studied by aerial photos. Landsc Urban Plan 31:21-37. doi:10.1016/0169-2046(94)01033-5

Jauni M, Hyvönen T (2012) Interactions between alien plant species traits and habitat characteristics in agricultural landscapes in Finland. Biol Invasions 14:47-63. doi:10.1007/s10530-011-0058-Z

Jentsch A, Kreyling J, Boettcher-Treschkow J, Beierkuhnlein C (2009) Beyond gradual warming: extreme weather events alter flower phenology of European grassland and heath species. Glob Chang Biol 15:837-849. doi:10.1111/j.1365-2486.2008.01690.x

Jump AS, Peñuelas J (2005) Running and stand still: adaptation and the response of plants to rapid climate change. Ecol Lett 8:1010-1020. doi:10.1111/j.1461-0248.2005.00796.x

Jump AS, Peñuelas J, Rico L et al (2008) Simulated climate change provokes rapid genetic change in the Mediterranean shrub Fumana thymifolia. Glob Chang Biol 14:637-643. doi:10.1111/j.1365-2486. 2007.01521.x 
Kaukoranta T, Hakala K (2008) Impact of spring warming on sowing times of cereal, potato and sugar beet in Finland. Agric Food Sci 17: 165-176

Keddy PA (1992) Assembly and response rules: two goals for predictive community ecology. J Veg Sci 3:157-165. doi:10.2307/3235676

Kolarova M, Tyser L, Soukup J (2013) Survey about the weed occurrence on arable land in the Czech Republic. Sci Agric Bohem 44:63-69. doi: $10.7160 / \mathrm{sab} .2013 .440210$

Kubisch A, Degen T, Hovestadt T, Poethke HJ (2013) Predicting range shifts under global change: the balance between local adaptation and dispersal. Ecography (Cop) 36:873-882. doi:10.1111/j.1600-0587. 2012.00062.x

Lauer E (1953) Über die Keimtemperaturen von Ackerunkräutern und deren Einfluß auf die Zusammensetzung von Unkrautgesellschaften. Flora 140:551-595

Lavergne S, Mouquet N, Thuiller W, Ronce O (2010) Biodiversity and climate change: integrating evolutionary and ecological responses of species and communities. Annu Rev Ecol Evol Syst 41:321-350. doi:10.1146/annurev-ecolsys-102209-144628

Lavorel S, Garnier E (2002) Predicting changes in community composition and ecosystem functioning from plant traits: revisiting the Holy Grail. Funct Ecol 16:545-556. doi:10.1046/j.1365-2435.2002.00664.x

Lavorel S, Prieur-Richard A-H, Grigulis K (1999) Invasibility and diversity of plant communities: from patterns to processes. Divers Distrib 5:41-49. doi:10.1046/j.1472-4642.1999.00034.x

Levin DA (2009) Flowering-time plasticity facilitates niche shifts in adjacent populations. New Phytol 183:661-666. doi:10.1111/j. 1469-8137.2009.02889.x

Linhart YB, Grant MC (1996) Evolutionary significance of local genetic differentiation in plants. Annu Rev Ecol Syst 27:237-277. doi:10. 1146/annurev.ecolsys.27.1.237

Lloret F, Médail F, Brundu G et al (2005) Species attributes and invasion success by alien plants on Mediterranean islands. J Ecol 93: 512-520. doi:10.1111/j.1365-2745.2005.00979.x

Lobell DB, Burke MB (2008) Why are agricultural impacts of climate change so uncertain? The importance of temperature relative to precipitation. Environ Res Lett 3:1-8. doi:10.1088/1748-9326/3/3/ 034007

Lohmeyer W (1954) über die Herkunft einiger nitrophiler Unkräuter Mitteleuropas. Vegetatio 5(6):63-65

Lososova Z, Simonova D (2008) Changes during the 20th century in species composition of synanthropic vegetation in Moravia (Czech Republic). Preslia 80:291-305

Lososova Z, Chytry M, Kühn I et al (2006) Patterns of plant traits in annual vegetation of man-made habitats in Central Europe. Perspect Plant Ecol Evol Syst 8:69-81. doi:10.1016/j.ppees.2006.07.001

Loss SR, Terwilliger LA, Peterson AC (2011) Assisted colonization: integrating conservation strategies in the face of climate change. Biol Conserv 144:92-100. doi:10.1016/j.biocon.2010.11.016

MacArthur RH (1955) Fluctuations of animal populations and a measure of community stability. Ecology 36:533-536. doi:10.2307/1929601

MacArthur RH (1970) Species-packing and competitive equilibrium for many species. Theor Popul Biol 1:1-11. doi:10.1016/00405809(70)90039-0

Maillet J, Lopez-Garcia C (2000) What criteria are relevant for predicting the invasive capacity of a new agricultural weed? The case of invasive American species in France. Weed Res 40:11-26. doi:10. 1046/j.1365-3180.2000.00171.x

Maron JL, Elmendorf SC, Vila M (2007) Contrasting plant physiological adaptation to climate in the native and introduced range of Hypericum perforatum. Evolution (N Y) 61:1912-1924. doi:10. 1111/j.1558-5646.2007.00153.x

May RM, MacArthur RH (1972) Niche overlap as a function of environmental variability. Proc Natl Acad Sci U S A 69:1109-1113

McDonald A, Riha S, DiTommaso A, DeDaetano A (2009) Climate change and the geography of weed damage: analysis of U.S. maize systems suggests the potential for significant range transformations. Agric Ecosyst Environ 130:131-140. doi:10.1016/j.agee.2008.12.007

McGill BJ, Enquist BJ, Weiher E, Westoby M (2006) Rebuilding community ecology from functional traits. TRENDS Ecol Evol 21:178185. doi:10.1016/j.tree.2006.02.002

McIntyre S, Lavorel S, Landsberg J, Forbes TDA (1999) Disturbance response in vegetation - towards a global perspective on functional traits. J Veg Sci 10:621-630. doi:10.2307/3237077

Mehrtens J, Schulte M, Hurle K (2005) Unkrautflora in Mais - Ergebnisse eines Monitorings in Deutschland. Gesunde Pflanz 57:206-218. doi:10.1007/s10343-005-0097-4

Meissle M, Mouron P, Musa T et al (2010) Pests, pesticide use and alternative options in European maize production: current status and future prospects. J Appl Entomol 134:357-375. doi:10.1111/j. 1439-0418.2009.01491.x

Menzel A, Sparks TH, Estrella N et al (2006) European phenological response to climate change matches the warming pattern. Glob Chang Biol 12:1969-1976. doi:10.1111/j.1365-2486.2006.01193.x

Milakovic I, Fiedler K, Karrer G (2014) Management of roadside populations of invasive Ambrosia artemisiifolia by mowing. Weed Res 54:256-264. doi:10.1111/wre.12074

Morin X, Thuiller W (2009) Comparing niche- and process-based models to reduce prediction uncertainty in species range shifts under climate change. Ecology 90:1301-1313

Morison JIL, Lawlor DW (1999) Interactions between increasing CO2 concentration and temperature on plant growth. Plant Cell Environ 22:659-682. doi:10.1046/j.1365-3040.1999.00443.x

Mortensen DA, Bastiaans L, Sattin M (2000) The role of ecology in the development of weed management systems: an outlook. Weed Res 49:49-62. doi:10.1046/j.1365-3180.2000.00174.x

Navas M-L (2012) Trait-based approaches to unravelling the assembly of weed communities and their impact on agro-ecosystem functioning. Weed Res 52:479-488. doi:10.1111/j.1365-3180.2012.00941.x

Neve P, Vila-Aiub M, Roux F (2009) Evolutionary-thinking in agricultural weed management. New Phytol 184:783-793. doi:10.1111/j. 1469-8137.2009.03034.x

Nogues-Bravo D (2009) Predicting the past distribution of species climatic niches. Glob Ecol Biogeogr 18:521-531. doi:10.1111/j.14668238.2009.00476.x

Novak R, Dancza I, Szentey L, Karaman J (2009) Arable weeds of Hungary. Fifth national weed survey (2007-2008). Minist Agric Rural Dev Hungary 95

Olesen JE, Bindi M (2002) Consequences of climate change for European agricultural productivity, land use and policy. Eur J Agron 16:239-262. doi:10.1016/S1161-0301(02)00004-7

Otte A (1991) Agro-ökosysteme und Habitatinseln in der Agrarlandschaft. 1. Agroökosysteme. 1.1 Struktur und Dynamik. Veränderungen im Keimungs- und Auflaufverhalten bei Chenopodium ficifolium im Vergleich von $1950 \mathrm{zu}$ 1985-88. Wissenschaftliche Beiträge der Martin-Luther-Universität HalleWittenberg R P Biowissenschaftliche Beiträge 46:38-48

Otte A, Bissels S, Waldhardt R (2006) Samen-, Keimungs- und Habitateigenschaften: Welche Parameter erklären Veränderungstendenzen in der Häufigkeit von Ackerwildkräutern in Deutschland? J Plant Dis Prot Sonderheft 20:507-516

Patterson DT (1995) Weeds in a changing climate. Weed Sci 43: 685-701

Patterson DT, Flint EP, Beers JL (1984) Effects of CO2 enrichment on competition between a $\mathrm{C} 4$ weed and a C3 crop. Weed Sci 32:101-105

Pautasso M, Dehnen-Schmutz K, Holdenrieder O et al (2010) Plant health and global change - some implications for landscape management. Biol Rev 85:729-755. doi:10.1111/j.1469-185X.2010.00123.x

Pearman PB, Guisan A, Broennimann O, Randin CF (2008) Niche dynamics in space and time. Trends Ecol Evol 23:149-158. doi: 10.1016/j.tree.2007.11.005 
Pearson RG, Dawson TP (2003) Predicting the impacts of climate change on the distribution of species: are bioclimate envelope models useful? Glob Ecol Biogeogr 12:361-371. doi:10.1046/j.1466822X.2003.00042.X

Pearson RG, Dawson TP, Liu C (2004) Modelling species distributions in Britain: a hierarchical integration of climate and land-cover data. Ecography (Cop) 27:285-298. doi:10.1111/j.0906-7590.2004. 03740.x

Peters K, Gerowitt B (2014) Response of the two rare arable weed species Lithospermum arvense and Scandix pecten-veneris to climate change conditions. Plant Ecol 215:1-11. doi:10.1007/s11258-0140358-3

Peters K, Porembski S, Gerowitt B (2009) Entwicklung, Samenbildung und Biomasseproduktion ausgewählter Problemunkrautarten in Rapshalbzwerghybriden. Gesunde Pflanz 61:101-106. doi:10. 1007/s10343-009-0207-9

Petit JR, Jouzel J, Raynaud D et al (1999) Climate and atmospheric history of the past 420,000 years from the Vostok ice core, Antarctica. Nature 399:429-436. doi:10.1038/20859

Petit S, Boursault A, Le Guilloux M et al (2011) Weeds in agricultural landscapes. A review. Agron Sustain Dev 31:309-317. doi:10.1051/ agro/2010020

Petitpierre B, Kueffer C, Broennimann O et al (2012) Climatic niche shifts are rare among terrestrial plant invaders. Science 335:1344 1348. doi:10.1126/science. 1215933

Pompe S, Hanspach J, Badeck F et al (2008) Climate and land use change impacts on plant distributions in Germany. Biol Lett 4:564-567. doi: 10.1098/rsbl.2008.0231

Pompe S, Berger S, Bergmann J et al (2011) Modellierung der Auswirkungen des Klimawandels auf die Flora und Vegetation in Deutschland. BfN-Skripten 304:1-193

Poorter H, Navas M-L (2003) Plant growth and competition at elevated CO2: on winners, losers and functional groups. New Phytol 157: 175-198. doi:10.1046/j.1469-8137.2003.00680.x

Post E, Forchhammer MC, Stenseth NC, Callaghan TV (2001) The timing of life-history events in a changing climate. Proc R Soc London, Ser B 268:15-23. doi:10.1098/rspb.2000.1324

Potts GR, Ewald JA, Aebischer NJ (2010) Long-term changes in the flora of the cereal ecosystem on the Sussex Downs, England, focusing on the years 1968-2005. J Appl Ecol 47:215-226. doi:10.1111/j.13652664.2009.01742.x

Pysek P, Jarosik V, Kropac Z et al (2005) Effects of abiotic factors on species richness and cover in Central European weed communities. Agric Ecosyst Environ 109:1-8. doi:10.1016/j.agee.2005.02.018

Rauber R (1977) Evolution von Unkräutern. Zeitschrift für Pflanzenkrankheiten und Pflanzenschutz, Sonderh 8:37-55

Raunkiaer C (1934) The life forms of plants and statistical plant geography. Oxford Univ Press, Oxford

Rejmanek M (1989) Invasibility of plant communities. In: Drake JA, Mooney HA (eds) Biological invasions. A global perspective. Wiley, Chichester, pp 369-388

Richardson DM, Pysek P (2006) Plant invasions: merging the concepts of species invasiveness and community invasibility. Prog Phys Geogr 30:409-431. doi:10.1191/0309133306pp490pr

Richardson AD, Keenan TF, Migliavacca M et al (2013) Climate change, phenology, and phenological control of vegetation feedbacks to the climate system. Agric For Meteorol 169:156-173. doi:10.1016/j. agrformet.2012.09.012

Robinson TMP, Gross KL (2010) The impact of altered precipitation variability on annual weed species. Am J Bot 97:1625-1629. doi:10. 3732/ajb. 1000125

Rogers HH, Runion GB, Prior SA et al (2008) Effects of elevated atmospheric $\mathrm{CO} 2$ on invasive plants: comparison of purple and yellow nutsedge (Cyperus rotundus L. and C. esculentus L.). J Environ Qual 37:395-400. doi:10.2134/jeq2007.0155
Sakai AK, Allendorf FW, Holt JS et al (2001) The population biology of invasive species. Annu Rev Ecol Evol Syst 32:305-332. doi:10. 1146/annurev.ecolsys.32.081501.114037

Sala OE, Chapin FS III, Armesto JJ et al (2000) Global biodiversity scenarios for the year 2100. Science 287:1770-1774. doi:10.1126/ science.287.5459.1770

Salonen J, Hyvönen T, Jalli H (2001) Weeds in spring cereals in Finland - a third survey. Agric Food Sci Finl 10:347-364

Salonen J, Hyvönen T, Kaseva J, Jalli H (2013) Impact of changed cropping practices on weed occurrence in spring cereals in Finland - a comparison of surveys in 1997-1999 and 2007-2009. Weed Res 53:110-120. doi:10.1111/wre.12004

Samhouri JF, Levin PS, Ainsworth CH (2010) Identifying thresholds for ecosystem-based management. PLoS One 5:e8907. doi:10.1371/ journal.pone. 0008907

Scheffer M, Carpenter S, Foley JA et al (2001) Catastrophic shifts in ecosystems. Nature 413:591-596. doi:10.1038/35098000

Schroeder D, Mueller-Schaerer H, Stinson CSA (1993) A European weed survey in 10 major crop systems to identify targets for biological control. Weed Res 33:449-458. doi:10.1111/j.1365-3180.1993. tb01961.x

Schulze E-D, Mooney HA (1994) Biodiversity and ecosystem function. Springer, New York, 531 pp

Silc U, Vrbnicanin S, BoziC D et al (2009) Weed vegetation in the northwestern Balkans: diversity and species composition. Weed Res 49: 602-612. doi:10.1111/j.1365-3180.2009.00726.x

Silvertown J (2004) Plant coexistence and the niche. TRENDS Ecol Evol 19:605-611

Singer A, Travis JMJ, Johst K (2013) Interspecific interactions affect species and community responses to climate shifts. Oikos 122:358-366. doi:10.1111/j.1600-0706.2012.20465.x

Skov F, Svenning J-C (2004) Potential impact of climatic change on the distribution of forest herbs in Europe. Ecography (Cop) 27:366 380. doi:10.1111/j.0906-7590.2004.03823.x

Smith RG (2006) Timing of tillage is an important filter on the assembly of weed communities. Weed Sci 54:705-712. doi:10.1614/WS-05177R1.1

Smith C, van Klinken RD, Seabrook L, McAlpine C (2011) Estimating the influence of land management change on weed invasion potential using expert knowledge. Divers Distrib 1:1-14. doi:10.1111/j. 1472-4642.2011.00871.x

Stohlgren TJ, Binkley D, Chong GW et al (1999) Exotic plant species invade hot spots of native plant diversity. Ecol Monogr 69:25-46. doi:10.1890/0012-9615(1999)069[0025:EPSIHS]2.0.CO;2

Stratonovich P, Storkey J, Semenov MA (2012) A process-based approach to modelling impacts of climate change on the damage niche of an agricultural weed. Glob Chang Biol 18:2071-2080. doi:10. 1111/j.1365-2486.2012.02650.x

Summers DM, Bryan BA, Crossman ND, Meyer W (2012) Species vulnerability to climate change: impacts on spatial conservation priorities and species representation. Glob Chang Biol 18:23352348. doi:10.1111/j.1365-2486.2012.02700.x

Sutcliffe OL, Kay QON (2000) Changes in the arable flora of central southern England since the 1960s. Biol Conserv 93:1-8. doi:10. 1016/S0006-3207(99)00119-6

Tanaka R, Koike F (2011) Prediction of species composition of plant communities in a rural landscape based on species traits. Ecol Res 26:27-36. doi:10.1007/s11284-010-0749-4

Tokatlidis IS (2013) Adapting maize crop to climate change. Agron Sustain Dev 33:63-79. doi:10.1007/s13593-012-0108-7

Tubiello FN, Soussana J-F, Howden SM (2007) Crop and pasture response to climate change. Proc Natl Acad Sci 104:19686-19690. doi:10.1073/pnas.0701728104

Tungate KD, Israel DW, Watson DM, Rufty TW (2007) Potential changes in weed competitiveness in an agroecological system with elevated 
temperatures. Environ Exp Bot 60:42-49. doi:10.1016/j.envexpbot. 2006.06.001

Von der Lippe M, Bullock JM, Kowarik I et al (2013) Human-mediated dispersal of seeds by the airflow of vehicles. PLoS One 8:1-10. doi: 10.1371/journal.pone. 0052733

Walck JL, Hidayati SN, Dixon KW et al (2011) Climate change and plant regeneration from seed. Glob Chang Biol 17:2145-2161. doi:10. 1111/j.1365-2486.2010.02368.x

Walther G-R, Post E, Convey P et al (2002) Ecological responses to recent climate change. Nature 416:389-395. doi:10.1038/416389a

Walther G-R, Roques A, Hulme PE et al (2009) Alien species in a warmer world: risks and opportunities. Trends Ecol Evol 24:686-693. doi: 10.1016/j.tree.2009.06.008

Wang R-L, Dekker J (1995) Weedy adaptation in Setaria spp.: III. Variation in herbicide resistance in Setaria spp. Pestic Biochem Physiol 51:99-116. doi:10.1006/pest.1995.1011

Warwick SI, Black LD (1986) Genecological variation in recently established populations of Abutilon theophrasti (velvetleaf). Can J Bot 64:1632-1643. doi:10.1139/b86-219

Webber BL, Le Maitre DC, Kriticos DJ (2012) Comment on climatic niche shifts are rare among terrestrial plant invaders. Science 338: 193-194. doi:10.1126/science.1225980

Weber E, Gut D (2005) A survey of weeds that are increasingly spreading in Europe. Agron Sustain Dev 25:109-121. doi:10.1051/agro:2004061

Weiher E, van der Werf A, Thompson K et al (1999) Challenging Theophrastus: a common core list of plant traits for functional ecology. J Veg Sci 10:609-620. doi:10.2307/3237076

Westerman PR, Diesterheft J, Gerowitt B (2012) Phenology of velvetleaf (Abutilon theophrasti Medic.) populations grown in northern
Germany. Julius-Kühn-Archiv 434:595-600. doi:10.5073/jka. 2012.434.076

Wiens JJ, Graham CH (2005) Niche conservatism: integrating evolution, ecology, and conservation biology. Annu Rev Ecol Evol Syst 36: 519-539. doi:10.1146/annurev.ecolsys.36.102803.095431

Wilson JB, Agnew ADQ (1992) Positive-feedback switches in plantcommunities. Adv Ecol Res 23:263-336. doi:10.1016/S00652504(08)60149-X

Woodward FI, Cramer W (1996) Plant functional types and climatic changes: introduction. J Veg Sci 7:306-308. doi:10.1111/j.16541103.1996.tb00489.x

Zangerl AR, Bazzaz FA (1984) The response of plants to elevated CO2II. Competitive interactions among annual plants under varying light and nutrients. Oecologia 62:412-417

Ziska LH (1997) Bunce JA (1997) Influence of increasing carbon dioxide concentration on the photosynthetic and growth stimulation of selected C4 crops and weeds. Photosynth Res 54:199-208. doi:10. 1023/A:1005947802161

Ziska LH (2003) Evaluation of the growth response of six invasive species to past, present and future atmospheric carbon dioxide. J Exp Bot 54:395-404. doi:10.1093/jxb/erg027

Ziska LH, Teasdale JR, Bunce JA (1999) Future atmospheric carbon dioxide may increase tolerance to glyphosate. Weed Sci 47:608-615

Ziska LH, Morris CF, Goins EW (2005) Quantitative and qualitative evaluation of selected wheat varieties released since 1903 to increasing atmospheric carbon dioxide: can yield sensitivity to carbon dioxide be a factor in wheat performance? Glob Chang Biol 10: 1810-1819. doi:10.1111/j.1365-2486.2004.00840.x 